\title{
Medical students' perspective on the place of team-based learning in the curriculum
}

This article was published in the following Dove Press journal:

Advances in Medical Education and Practice

\section{Anass Nuur Ali \\ Khamees Elbayouk \\ Abdirahman Osman}

Faculty of Medicine, St George's Hospital Medical School, London, UK
Correspondence: Abdirahman Osman Faculty of Medicine, St George's Hospital Medical School, Cranmer Terrace, London SWI7 ORE, UK

Tel +44 795073 I276

Email abdirahman97@hotmail.co.uk

\section{Dear editor}

We read with great interest the recent article by Yan et al ${ }^{1}$ discussing the use of TeamBased Learning (TBL) in medical school. As medical students, our exposure to a number of different learning methods allows us to offer a unique perspective on the effectiveness of TBL.

Yan et $\mathrm{al}^{1}$ explored the need for a more innovative learning method that allows a deeper understanding of the medical sciences. Long gone are the days where traditional lectures form the foundation for teaching of the medical curriculum. In the millennial world, higher education is quickly advancing from teacher-centered instruction to a much more student-centered approach. The extent to which this should be applied in the medical curriculum is where the discussion lies. TBL champions the student-centered approach; those taught through this model reported improved enthusiasm and development of skill-based characteristics. Another notable advantage of TBL mentioned in Faezi et al's article ${ }^{2}$ is a slower rate of decline in scores after the TBL sessions. Although TBL has many benefits, it is important to note that it does not address all the shortcomings in the medical curriculum. The question still stands - to which extent should TBL be implemented in the general teaching of medical students?

We believe the effectiveness of TBL is dependent on the willingness of students to engage with content. Many believe that pre-reading for sessions can be excessive and better delivered through a lecture. ${ }^{3}$ Throughout the year, students experience a loss in motivation in the absence of teaching. Students are then less likely to attend sessions with the increasing workload, which is worsened by a perceived lack of their own ability to cope and poor time management. This results in a spiral effect where educational issues further impact upon motivation. ${ }^{4}$ While it is important to appreciate the individual and group benefits of TBL, we should not neglect providing a studentcentered method that can be personalized by millennial learners.

TBL is of great use to educators for its potential to increase depth of understanding and engagement. However, we feel that the use of TBL as the sole teaching method may not provide the solution to the drawbacks of traditional teaching. A student-centered approach is far more beneficial and caters for the educational needs of all students. We suggest a synergistic approach between TBL and traditional lectures. This hybrid has the potential to increase student satisfaction, boost total scores, and cater to all students. ${ }^{5}$ We believe that this approach holds promise 
in providing an equal educational platform and a more personalized approach to active learning.

\section{Disclosure}

The authors report no conflicts of interest in this communication.

\section{References}

1. Yan J, Ding X, Xiong L, et al. Team-based learning: assessing the impact on anatomy teaching in People's Republic of China. Adv Med Educ Pract. 2018;9:589-594.
2. Faezi ST, Moradi K, Ghafar Rahimi Amin A, Akhlaghi M, Keshmiri F. The effects of team-based learning on learning outcomes in a course of rheumatology. J Adv Med Educ Prof. 2018;6(1):22-30.

3. Bick RJ, Oakes JL, Actor JK, et al. Interactive teaching: problem solving and integration of basic science concepts into clinical scenarios using team based learning. J Int Assoc Med Sci Educ. 2010;19(1) :26-34.

4. Najimi A, Sharifirad G, Amini MM, Meftagh SD. Academic failure and students' viewpoint: The influence of individual, internal and external organizational factors. $J$ Educ Health Promot. 2013;2:22.

5. Yang LH, Jiang LY, Xu B, et al. Evaluating team-based, lecture-based, and hybrid learning methods for neurology clerkship in China: a method-comparison study. BMC Med Educ. 2014;14:98. 


\section{Author's reply Junhao Yan}

Department of Anatomy and Histology, School of Basic Medical Sciences, Peking University, Beijing 100191, People's Republic of China

Correspondence: Junhao Yan

Department of Anatomy and Histology, School of Basic Medical Sciences, Peking University, No. 38 Xueyuan Road, Beijing 100191,

People's Republic of China

Tel/fax +86 I0 $8280 \quad 1466$

E-mail yjh@bjmu.edu.cn

\section{Dear editor}

We do agree with the opinion of Abdirahman Osman et al. The pre-reading for the sessions might increase the student's burden, and sometimes, the traditional teaching method can improve the reading efficiency for the students. Therefore, it is better to establish a synergistic approach or balance between the TBL and traditional lectures. We do thank the team of Professor Abdirahman Osman for their valuable suggestion.

\section{Disclosure}

The author reports no conflicts of interest in this communication.

Dove Medical Press encourages responsible, free and frank academic debate. The content of the Advances in Medical Education and Practice 'letters to the editor' section does not necessarily represent the views of Dove Medical Press, its officers, agents, employees, related entities or the Advances in Medical Education and Practice editors. While all reasonable steps have been taken to confirm the content of each letter, Dove Medical Press accepts no liability in respect of the content of any letter, nor is it responsible for the content and accuracy of any letter to the editor.

\section{Publish your work in this journal}

Advances in Medical Education and Practice is an international, peerreviewed, open access journal that aims to present and publish research on Medical Education covering medical, dental, nursing and allied health care professional education. The journal covers undergraduate education, postgraduate training and continuing medical education including emerging trends and innovative models linking education, research, and health care services. The manuscript management system is completely online and includes a very quick and fair peer-review system. Visit http://www.dovepress.com/testimonials.php to read real quotes from published authors.

Submit your manuscript here: http://www.dovepress.com/advances-in-medical-education-and-practice-journal 